\title{
Dictatorships and the Worlds of Work in the Southern Cone: Argentina, Brazil and Chile
}

\author{
Peter Winn \\ Tufts University
}

Beginning with Brazil in 1964, continuing with Chile in 1973, and concluding with Argentina in 1976, the ABC powers of South America experienced civilmilitary coups and long-lived dictatorships that put an end to their democratic governments and programs of structural reform. Each coup reflected national circumstances and histories that differed from country to country-in Brazil, the military overthrew João Goulart's left populist government, in Chile, the Pinochet coup put an end to Allende's democratic road to socialism, while in Argentina, the military Junta and their civilian allies ended the left Peronist "revolutionary" project (already under attack from the Peronist right) and replaced it with a rightist "process" of their own.

Despite these differences, what these Southern Cone dictatorships all had in common was their anti-labor stance and their determination to break the power of organized labor, restrict labor rights, and tilt the field of labor relations in favor of business. As a result of their anti-labor character, workers and their leaders were among the chief victims of their political repression and social control. In Argentina, for example, the National Commission on the Disappearance of Persons (CONADEP) official truth commission concluded that roughly one third of the victims of the Junta were workers, a figure that Victoria Basualdo argues is a lower bound that does not take into consideration white collar workers or that many students were also workers.

Yet, despite this high proportion of worker victims, the image of the typical victim of the abuse of human rights by these South American dictatorships as diffused by the media, the human rights organizations, and subsequent scholars is one of an idealistic middle-class university student. Perhaps this is because the people who write the books and articles about the dictatorships and their human rights abuses are the survivors of those student groups, and many of them are now established academics.

As a result, the workers who were "disappeared" by the dictatorships have been disappeared a second time - this time from the history and memory of that era. It was this double disappearance of workers in southern South America that led Paulo Fontes and Larissa Correa (and their colleagues) to organize the First "Seminário Internacional Mundos do Trabalho e Ditaduras no Cone Sul" conference in Rio de Janeiro in October 2015, with a follow-up conference organized by Victoria Basualdo that took place in Buenos Aires in 2016. These conferences revealed that there were many scholars, including many younger scholars, who were interested in these themes, but whose work was not widely 
diffused. It also confirmed that the experience of workers, their organizations, and their leaders under the dictatorships of Argentina, Brazil, and Chile of the 1960s, 1970s, and 1980s had not received the scholarly attention that it deserved-and that it constituted a silence in the history and memory of that important era that needed to be addressed.

This mini-special issue of ILWCH is a step in that direction, bringing together in three historiographical articles, written by leading labor historians of Argentina, Brazil, and Chile, the national experiences of their dictatorships by the workers of the three countries.

In conceiving the mini-special issue, I asked leading scholars-Victoria Basualdo, Larissa Correa, Paulo Fontes, and Angela Vergara - to synthesize their work with that of other scholars, including as yet unpublished research, into a concise historiographical overview that would be intelligible to ILWCH readers who are not specialists in Latin America and its labor history.

The result is a mini-issue that can serve as a sophisticated introduction for readers with little knowledge of South America and its labor history or as a comprehensive historiography for those who share the specialization and even for those who want to do research of their own and see these articles as a place to take off from and go beyond. Moreover, despite the differences in their national histories, the three articles all share common questions that create parallel analyses, a chronological structure that enables historicizing of memory, and agendas for future research.

Another shared characteristic is that their workers are not passive victims, but rather key protagonists of the pre-coup era-in their workplaces, their unions, and the streets - and the strongest support base of progressive structural reforms. Indeed, it was the growing power of organized workers under democracy in all three countries that persuaded civil and military elites that democracy could not be trusted to protect their core interests and that motivated the civilmilitary coups that ended democracy and inaugurated lengthy anti-labor dictatorships.

Moreover, all three articles share a common structure, which lends them a double identity: They are a history of the experience of workers under dictatorship and a historiography of that theme in subsequent studies of history and memory. That common structure also enables a common strategy: These studies have to be historicized, which makes these three articles also histories of the post-dictatorship eras.

All three articles end with unanswered questions that constitute a future research agenda. All three call for decentered research that analyzes the experience of workers outside the political and economic centers, including that of rural workers. Angela Vergara points to the need to incorporate the gendered, environmental, transnational, and social consequences of the Pinochet dictatorship and to study worker consumption as well as worker production. Paulo Fontes and Larissa Correa conclude that the relationship of workers and unions to the Brazilian state remains an issue that needs further research, as does the emergence of the "new" unionism symbolized by Lula. But they also 
underscore the need to study the experience of rural workers in a country where they were a large part of the work force and played a dynamic role in the resistance. Another area that Fontes and Correa consider both important and inadequately explored is the relationship between workers and armed resistance, an open question that is even more important in Argentina, where the Center and Right have made the presence of armed "revolutionary" groups the basis for the "theory of the two demons," in which the asymmetric political violence of the Left and Right are equated and are blamed for the dictatorship and its human rights violations. Victoria Basualdo also stresses the need to examine the complicity of capital in the violations of human rights in general and labor rights particularly in Argentina. This is a relevant theme in Brazil and Chile as well.

Lastly, a question that this introduction and the three articles it contextualizes only begin to explore is the comparative history of workers under dictatorship, both within South America and the world beyond. For unfortunately, Argentina, Brazil, and Chile are not the only nations in the region or the wider world where workers have suffered the repression of military coups and dictatorships. In too many places in today's world, workers are facing antilabor authoritarian regimes. That might be an appropriate theme for a full special issue with global reach.

This mini-special issue on the Southern Cone is a start. 